\title{
Petrography, Geochemistry and Petrogensis of Pleistocene Basaltic Flow from Northwest Atarous Area, Central Jordan
}

\author{
Hassan Al-Fugha1, Ibrahim Ahmad Ali Bany Yaseen²* \\ ${ }^{1}$ Department of Environmental and Applied Geology, Faculty of Science, University of Jordan, Amman, Jordan \\ ${ }^{2}$ Department of Earth and Environmental Sciences, Institute of Earth and Environmental Sciences, Al-al-Bayt University, \\ Al-Mafraq, Jordan \\ Email: h.alfugha@ju.edu.j, „ibanyyaseen@Yahoo.com
}

How to cite this paper: Al-Fugha, H. and Yaseen, I.A.A.B. (2019) Petrography, Geochemistry and Petrogensis of Pleistocene Basaltic Flow from Northwest Atarous Area, Central Jordan. International Journal of Geosciences, 10, 613-631.

https://doi.org/10.4236/ijg.2019.106035

Received: April 3, 2019

Accepted: June 8, 2019

Published: June 11, 2019

Copyright $\odot 2019$ by author(s) and Scientific Research Publishing Inc. This work is licensed under the Creative Commons Attribution International License (CC BY 4.0).

http://creativecommons.org/licenses/by/4.0/

\begin{abstract}
Fifteen basaltic rock samples were collected from central Jordan at the Atarous volcanism basaltic flow area. The samples cover about $8 \mathrm{~km}^{2}$ from the Atarous Basalt flow (AB). The AB flow was introduced in the Miocene to Pleistocene periods. The samples analyze major and trace elements by using XRF. Petrography, Geochemistry and Petrogensis have investigation to carried out for the $\mathrm{AB}$. The petrography analyses of the $\mathrm{AB}$ rocks show they are composed of plagioclase (labradorite and bytownite), pyroxene (augite), and olivine (forsterite); accessory minerals include apatite and secondary minerals magnetite, ilmenite, spinel and iddingsite. The $\mathrm{AB}$ is classified within alkaline to sub-alkaline and tholeiitic to Calc-Alkaline basalt. The $\mathrm{Mg} \#$ range between 0.39 and 0.49 of basalt samples exhibits different degrees of fractionation with a low degree of melting $<15 \%$ as indicated from the varying concentration of incompatible trace elements $\mathrm{Ba}, \mathrm{Rb}, \mathrm{Sr}$. Trace elements of primary magna show low variable abundances of compatible and incompatible elements, which reflecs a homogenous source. Geochemical parameters such as $\mathrm{Mg \#}$ and high $\mathrm{Ti}$ contents indicate that the corresponding magmas are of primary origin. The tectonic setting of $\mathrm{AB}$ is explained by using discrimination diagrams, $\mathrm{Ti}-\mathrm{Zr}-\mathrm{Sr}$ and $\mathrm{Nb}-\mathrm{Zr}-\mathrm{Y}$ and $\mathrm{Ti}-\mathrm{Zr}-\mathrm{Y}$, the $\mathrm{AB}$ plotted within the plate basalt, alkali basalt and Calk alkaline basalt field, respectively. The spider diagram shows the samples $\mathrm{AB}$ enrichment of the $\mathrm{Ba}, \mathrm{K}, \mathrm{Nb}$ and $\mathrm{Ce}$, depletion of $\mathrm{Nb}$ and $\mathrm{Y}$. The $\mathrm{AB}$ exhibited positive $\mathrm{Nb}, \mathrm{Ce}$ and $\mathrm{Ti}$ anomalies, and negative anomalies of $\mathrm{Ba}, \mathrm{Sr}$, and $\mathrm{P}$. It is attributed to the fractionation of feldspar for $\mathrm{Ba}$ and $\mathrm{Sr}$ and apatite for $\mathrm{P}$ depletion. The spider diagram showed a positive $\mathrm{Nb}$ peak, which conforms to the tertiary and to recent continental alkali basalt provinces and indicates that the $\mathrm{AB}$ is the product of lithosphere from upwelling asthenosphere mantle.
\end{abstract}




\section{Keywords}

Petrography, Geochemistry, Petrogensis, Pleistocene Basaltic, Atarous Basalt, Jordan

\section{Introduction}

The studied area is located within the intraplate volcanic field in the Atarous Area of central Jordan. The volcanic cone is located at the eastern side of the Dead Sea area, $1 \mathrm{~km}$ northwest of Atarous Village. The volcanism occurs at the western margin of the Arabian plate and has been tectonically controlled by the Arabian plate movement, which moved northwards along the Dead Sea transform fault (Figure 1). These volcanoes are clearly associated with continental
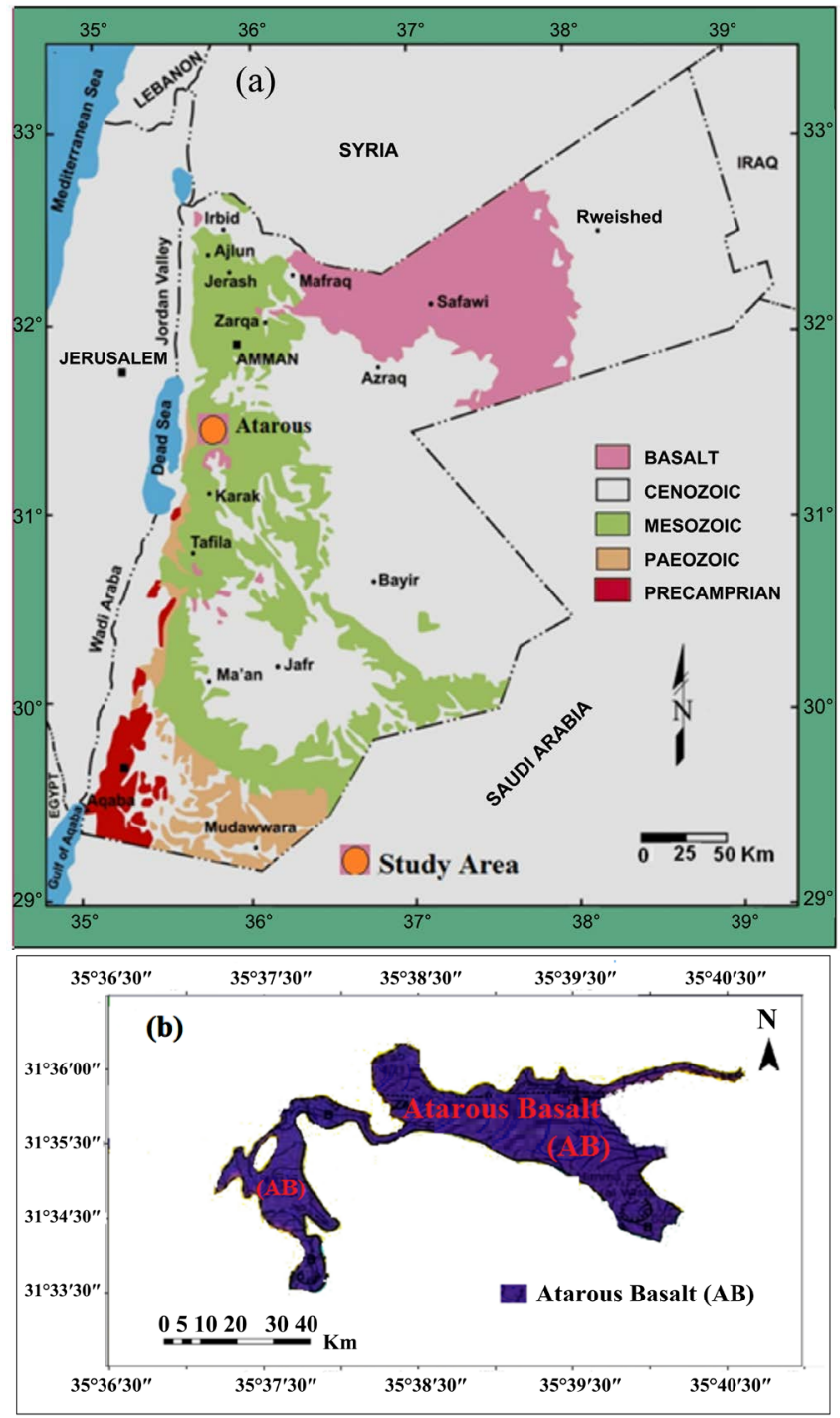

Figure 1. (a) Geological map of Jordan Showing Location of the Study Area, (b) Study Area for Atarous Basalt (AB) Rocks. 
rifting and inception of the Dead Sea plate boundary. The relationship between the magmatism and tectonics of the intraplate volcanism has been reported by [1], indicating that alkaline volcanism in Jordan is similar to the Arabian intraplate volcanic fields, which erupt through two main fissure systems along the eastern margin of the Dead Sea rift in the east-west direction [2] and [3].

The volcanism might have probably commenced during the Miocene period and continued to the Pleistocene [4]. The Cenozoic volcanism in central Jordan has a relatively long period of magmatic sequence extending from the Oligocene to the Holocene [1] and [5]. The basaltic lava poured from vertical fissures and local vents along the Jordan Rift mountain ridge in central Jordan and in northeast Jordan [6]. The Jordanian basalts are part of the Arabian plateau basalt that covers a large area in Saudi Arabia, Jordan and Syria.

In general, alkali basalts are widespread on continental plates and are usually associated with continental rifting [7]. This is also the environment of the extended young volcanic fields near the western margin of the Arabian plate, which is separated from the African plate by the Red Sea Rift. Such volcanic fields occur in Yemen, close to the triple junction with the East African Rift and the Aden Ridge, and northwards in Saudi Arabia, Jordan, Syria, Turkey and from the southern rim of the Damascus basin. It covers an area of about 11.400 $\mathrm{km}^{2}$. The extensive volcanism in northeastern Jordan occurred during faulting episodes and predominantly consisted of alkali basalts, basanites and hawaiites [1] and [8] ranged from 0.2 to $18.5 \mathrm{Ma}$ as determined by K-Ar dating [4] [9] [10] [11] [12]. In central Jordan volcanos, magmas transported upper mantle nodules with the composition of spinel lherzolite to the surface [13]. These xenoliths contain olivine, orthopyroxene, clinopyroxene and spinel as typical for the uppermost mantle below continental plates, analogous to worldwide occurrences [7] and [14] [15]. The objective of this study is to investigate the petrography, geochemistry, and petrogensis of the intercontinental basaltic flow at the Atarous Basalt Area (AB), which is in the east of the Dead Sea in central Jordan.

\section{Geologic Setting}

Jordan is part of the Arabian plate, which is drifting to the NE towards the Tauros-Zagros compressional zone due to the aforementioned opening of the Red Sea. This process is accompanied by the development of the Dead Sea transform fault, which trends north-south with a net slip along it of about $105 \mathrm{~km}$ [16] [17]. The volcanoes in the studied area are of stratovolcano type [18] [19] [20]. They rose above the surface of basalt flows by more than $120 \mathrm{~m}$. On the slopes of the volcano, finely grained ash, angular and spherical pyroclastic of a diameter of less than $0.2 \mathrm{~cm}$ and basaltic bombs of different sizes with diameters ranging between 0.5 and $1.2 \mathrm{~m}$ are exposed. Basaltic layers of blocky lava with an average thickness of $40 \mathrm{~cm}$ are also present. The tectonic evolution of the Arabian plate is determined by the main regional structures of the region, including the Red Sea rift and the Dead Sea transform fault, which trends north-south and the net 
slip along it is about $105 \mathrm{~km}$ [16] [17]. The study area is affected by different structures such as Zarqa-Main fault trending E-W direction and extending from the Dead Sea to Wadi Sirhan fault. The basalt intrudes along the fault and forms a volcanic neck. The $\mathrm{AB}$ occurs in the direction of N-S, E-W, NW-SE, and NE-SW, which coincide within the main regional and local structural fault directions. The fracture trending N-S are parallel to Zarqa-Ma'in fault, Suwaqa fault, Hasa fault, and Salwan fault perpendicular to the Dead Sea Transform Fault and Suwaqa normal fault [5]. The trending joints NE-SW was consistent with the late Pan-African stress pattern and are parallel to Amman Hallabat fault. The trending direction NW-SE is related to the regional faults, such as Karak Fayha fault and Wadi Sirhan fault, which extends from Saudi Arabia in the south and continuing to north Jordan.

\section{Sampling and Analytical Techniques}

A total of 15 representative rock chip samples were collected from the outcropping Atarous Basaltic ( $\mathrm{AB}$ ) cones in central Jordan (Figure 1). The samples are crushed and powdered using a stainless steel Jaw Crusher and an Agate Ball Mill machine to obtain grain size less than $(-80 \mu)$. The samples were quartered to get a statistically representative (splitter) fraction and powdered using two geochemical techniques at the labs of the mineralogy institute at the University of Stuttgart Germany. The major and trace elements were analyzed on fused glass discs-like pellet (bead) by using X-Ray Florescence Spectrometry (XRF) at the Department of Geology, University of Stuttgart (Germany). A total of 2 gram of the powder samples were mixed with 8 gram of lithium tetraborate and fused in platinum crucibles over gas burners $\left(1000^{\circ} \mathrm{C}\right)$ for $1 \mathrm{~h}$. The melts were poured into a mold to create glass disks. The Loss on Ignition (LOI) was determined by the weight lost after melting at $1000^{\circ} \mathrm{C}$. Thin sections were prepared at the University of Jordan and petrographically investigated via a polarizing microscope with different magnifications.

\section{Result}

\subsection{Petrography and Mineralogy}

The volcanic rocks of central Jordan are mainly composed of cinder cones, scoria and basaltic flows. The basaltic rocks in hand specimen are black to grey in color and fine-grained. The melanocratic rocks typically show porphyritic and trachytic texture and are characterized by olivine, augite and plagioclase phenocrysts embedded in a fine-grained groundmass that mainly consists of plagioclase, olivine, augite and glass. The average modal composition is 58 vol.\% plagioclase 21 vol.\% olivine, 16 vol.\% clinopyroxene and 5 vol.\% accessory minerals and glass.

Plagioclase occurs in tow generation as up to $(>3) \mathrm{mm}$ long hypidiomorphic laths and fine crystals in the groundmass. The sub-hedral plagioclase laths have compositions with 45 to $55 \mathrm{vol} . \%$, indicating labradorite to bytownite composi- 
tion. These were documented after [21] ternary for plagioclase diagram, all the samples sent within labradorite to bytownite field (Figure 2).

The olivine occurs as crystals are unhedral to sub-hedral, fractured, mostly unaltered and reach lengths of $2 \mathrm{~mm}$ and in the groundmass crystals. They are colorless to pale yellow-green. A few exceptions exhibit resorbed margins, which can be partly or completely replaced by iddingsite and chlorite. The olivine crystals are typically Magnesian in the basalt with a forsterite component.

The pyroxene (augite) crystals are colorless or pale brown to pale green, 0.5 to $4 \mathrm{~mm}$ in length. Perfect two set cleavage which intersected at $\sim 90^{\circ}$ in the cross-section. The pyroxene crystals had an inclined extinction between $43^{\circ}$ and $48^{\circ}$, indicating the presence of clinopyroxene of augite. The groundmass augite $<0.3 \mathrm{~mm}$. Small amounts of this augite are affected by chloritzation where green chlorite is present along fractures and crystal rims. The classification of pyroxene after [22] diagram, the samples plotted within augite field Figure 3. Accessory minerals include apatite as minute needles and opaque phases, which were

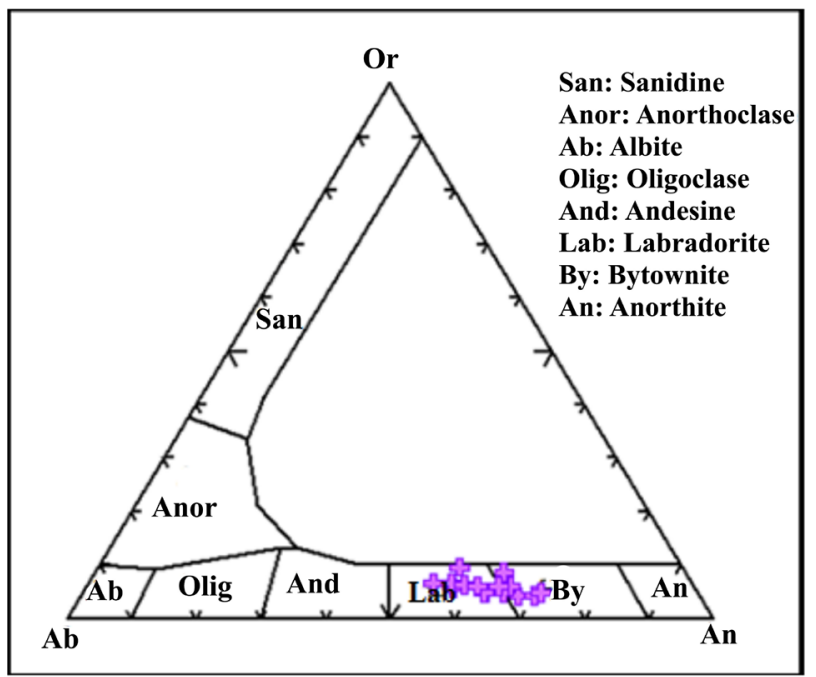

Figure 2. Ab-An-Or ternary for plagioclase of Atarous volcanic rocks, modified after [21].

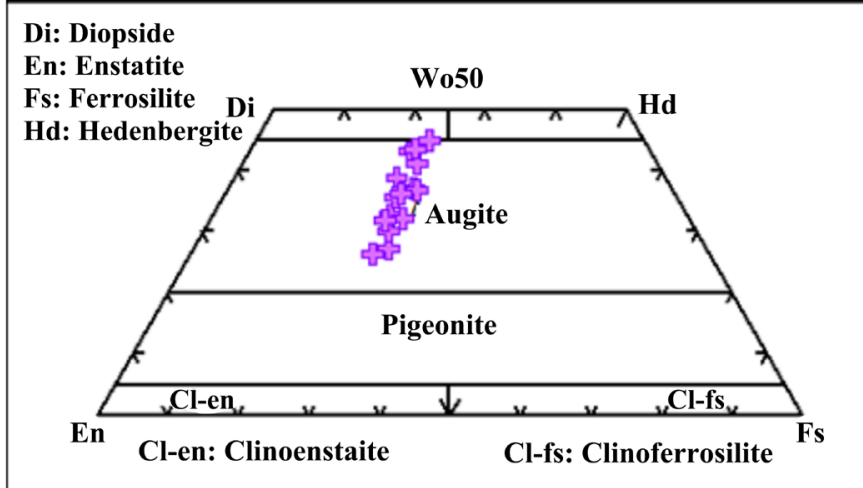

Figure 3. Classification of pyroxene from Atarous volcanic rocks after [22], all the sample study plotted within Augite field. 
identified as magnetite, ilmenite and spinel. These minerals generally make up about 5 vol.\% of the basalt.

\subsection{Geochemistry}

Fifteen samples of Pleistocene alkali basalts from central Jordan have been analyzed for major, minor, and trace elements. Representative results are given in Table 1. The $\mathrm{SiO}_{2}$ values range between 46.11 and $49.56 \mathrm{wt} \%$ within an average (47.86 wt\%), which is within the average value reported for alkali basalt and basanite by many authors [2] and [23] and it can be classified as basalt using the Total Alkalis-Silica classification scheme [23] [25] (Figure 4(a) and Figure 4(b)). The alkalis vs. silica in the [26] diagram, shows that all the rock samples
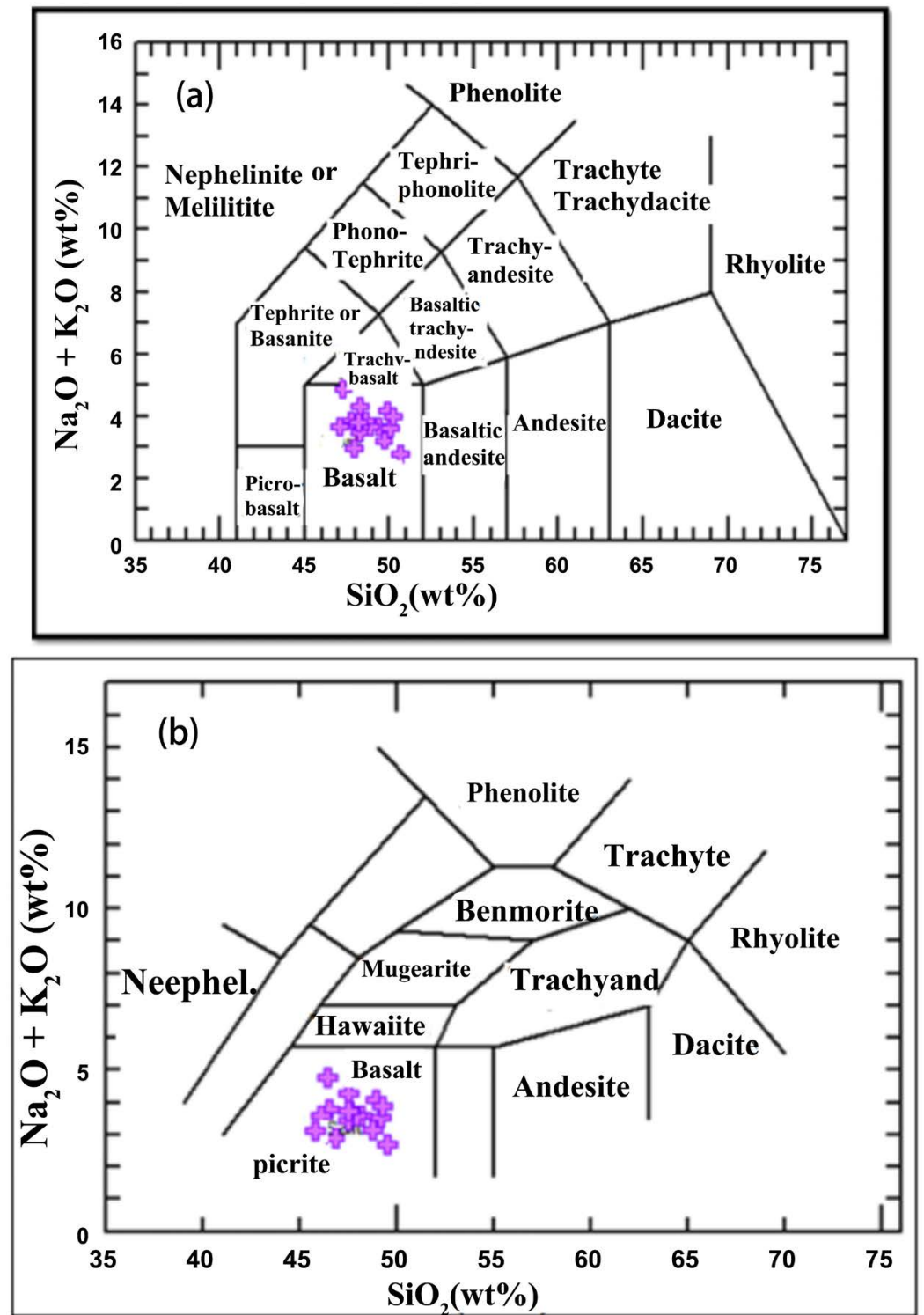

Figure 4. $\mathrm{SiO}_{2}$ vs. $\mathrm{Na}_{2} \mathrm{O}+\mathrm{K}_{2} \mathrm{O}$ (TAS) diagram after (a) [24]; (b) Showing the classification of volcanic rocks from Atarous volcanic rocks, all the rock samples study was plotted within the basalt field [25]. 
Table 1. Chemical analyses of Atarous Basalt Rock Sample study.

\begin{tabular}{|c|c|c|c|c|c|c|c|c|c|c|c|c|c|c|c|}
\hline Sample No & AT1 & AT2 & AT3 & AT4 & AT5 & AT6 & AT7 & AT8 & AT9 & AT10 & AT11 & AT12 & AT13 & AT14 & AT15 \\
\hline $\mathrm{SiO}_{2} \mathrm{wt} \%$ & 47.51 & 46.5 & 46.42 & 47.49 & 48.17 & 49.21 & 48.81 & 46.8 & 47.95 & 49.56 & 46.11 & 48.92 & 47.62 & 49.31 & 47.55 \\
\hline $\mathrm{TiO}_{2}$ & 1.66 & 1.67 & 2.89 & 1.71 & 1.4 & 1.48 & 1.43 & 1.87 & 1.98 & 1.54 & 1.89 & 1.6 & 1.55 & 1.42 & 1.62 \\
\hline $\mathrm{AI}_{2} \mathrm{O}_{3}$ & 14.58 & 13.4 & 13.73 & 14.92 & 15.27 & 15.36 & 14.87 & 15.5 & 15.93 & 15.11 & 15.12 & 14.44 & 14.62 & 14.2 & 14.75 \\
\hline $\mathrm{Fe}_{2} \mathrm{O}_{3}$ & 3.16 & 3.17 & 4.39 & 3.71 & 2.9 & 2.98 & 2.93 & 3.37 & 3.48 & 2.87 & 3.72 & 3.08 & 2.92 & 3.11 & 2.97 \\
\hline $\mathrm{FeO}$ & 9.12 & 8.82 & 8.41 & 8.09 & 9.01 & 9.05 & 8.54 & 8.79 & 7.67 & 9.65 & 9.08 & 9.25 & 9.66 & 9.17 & 9.31 \\
\hline $\mathrm{MnO}$ & 0.21 & 0.19 & 0.21 & 0.25 & 0.2 & 0.19 & 0.26 & 0.22 & 0.2 & 0.21 & 0.22 & 0.23 & 0.21 & 0.22 & 0.21 \\
\hline $\mathrm{MgO}$ & 8.75 & 8.35 & 7.92 & 6.95 & 7.16 & 6.96 & 6.08 & 6.95 & 6.24 & 8.94 & 8.08 & 7.95 & 9.15 & 9.72 & 9.27 \\
\hline $\mathrm{CaO}$ & 9.49 & 11.9 & 9.86 & 12.24 & 10.1 & 9.89 & 12.47 & 11.6 & 11.47 & 7.48 & 10.5 & 8.78 & 8.83 & 7.48 & 9.56 \\
\hline $\mathrm{Na}_{2} 0$ & 3.46 & 3.02 & 3.36 & 2.8 & 2.93 & 2.91 & 2.52 & 2.21 & 2.74 & 1.83 & 2.75 & 3.22 & 2.95 & 3.11 & 2.92 \\
\hline $\mathrm{K}_{2} \mathrm{O}$ & 0.8 & 0.75 & 1.43 & 0.63 & 0.65 & 0.65 & 0.64 & 0.68 & 0.87 & 0.87 & 0.84 & 0.87 & 0.81 & 0.79 & 0.82 \\
\hline $\mathrm{P}_{2} \mathrm{O}_{3}$ & 0.38 & 0.51 & 0.28 & 0.23 & 0.53 & 0.2 & 0.23 & 0.22 & 0.3 & 0.35 & 0.42 & 0.45 & 0.31 & 0.3 & 0.29 \\
\hline Sum & 99.12 & 98.2 & 98.9 & 99.02 & 98.32 & 98.88 & 98.78 & 98.2 & 98.83 & 98.41 & 98.73 & 98.79 & 98.63 & 98.83 & 99.27 \\
\hline LOI & 0.88 & 1.79 & 1.1 & 0.98 & 1.68 & 1.12 & 1.22 & 1.78 & 1.17 & 1.59 & 1.27 & 1.21 & 1.37 & 1.17 & 0.73 \\
\hline $\mathrm{Mg} \#$ & 0.49 & 0.49 & 0.49 & 0.45 & 0.44 & 0.44 & 0.42 & 0.44 & 0.45 & 0.42 & 0.39 & 0.39 & 0.42 & 0.44 & 0.43 \\
\hline \multicolumn{16}{|c|}{ Trace Elements (ppm) } \\
\hline $\mathrm{Sr}$ & 4350 & 5500 & 365 & 345 & 365 & 355 & 3750 & 425 & 375 & 380 & 375 & 360 & 365 & 392 & 325 \\
\hline $\mathrm{Zr}$ & 95 & 115 & 90 & 60 & 80 & 80 & 145 & 80 & 70 & 85 & 94 & 105 & 100 & 75 & 109 \\
\hline $\mathrm{Ni}$ & 160 & 164 & 143 & 108 & 115 & 106 & 106 & 106 & 73 & 142 & 155 & 150 & 162 & 168 & 157 \\
\hline $\mathrm{Cr}$ & 131.00 & 154 & 130 & 120 & 124 & 109 & 125 & 129 & 106 & 137 & 125 & 162 & 138 & 152 & 129 \\
\hline $\mathrm{Pb}$ & - & 95 & 100 & 55 & 15 & 75 & 63 & 80 & 55 & 60 & 82 & 94 & 42 & 65 & 30 \\
\hline $\mathrm{Ba}$ & 140 & 125 & 195 & 130 & 75 & 80 & 130 & 140 & 265 & 54 & 65 & 42 & 40 & 35 & 75 \\
\hline $\mathrm{Rb}$ & 8 & 10 & 12 & 14 & 9 & 11 & 15 & 10 & 12 & 8 & 10 & 11 & 16 & 9 & 7 \\
\hline $\mathrm{Nb}$ & 22 & 26 & 19 & 40 & 20 & 24 & 26 & 10 & 13 & 25 & 23 & 16 & 18 & 12 & 15 \\
\hline Y & 16 & 22 & 18 & 26 & 15 & 19 & 16 & 15 & 11 & 17 & 23 & 16 & 18 & 12 & 15 \\
\hline $\mathrm{Ce}$ & 45 & 70 & 66 & 55 & 46 & 61 & 66 & 47 & 25 & 25 & 31 & 34 & 22 & 46 & 35 \\
\hline \multicolumn{16}{|l|}{ CIPW Norms } \\
\hline Or & 4.71 & 4.47 & 8.48 & 3.74 & 3.86 & 3.85 & 3.8 & 4.05 & 5.15 & 5.112 & 5.04 & 4.11 & 4.95 & 5.62 & 4.66 \\
\hline $\mathrm{Ab}$ & 25.49 & 18.6 & 21.08 & 22.4 & 24.94 & 24.65 & 21.4 & 18.9 & 23.23 & 23.44 & 20.15 & 20.75 & 22.7 & 23.37 & 25.93 \\
\hline An & 21.81 & 20.9 & 18.23 & 20.43 & 26.75 & 26.96 & 27.48 & 30.5 & 28.68 & 26.62 & 21.3 & 28.87 & 24.7 & 24.64 & 21.95 \\
\hline $\mathrm{Ne}$ & 1.99 & 3.85 & 4.04 & 0.77 & 0 & 0 & 0 & 0 & 0 & 0.53 & 3.2 & 3.15 & 3.41 & 0 & 3.55 \\
\hline Wo & 9.45 & 14.6 & 12.12 & 13.83 & 8.42 & 8.71 & 13.83 & 11 & 11.03 & 9.08 & 10.8 & 4.2 & 8.65 & 4.65 & 8.27 \\
\hline En & 5.78 & 9.04 & 8.14 & 8.34 & 10.4 & 12.55 & 12.02 & 11.7 & 9.76 & 5.39 & 6.35 & 18.6 & 6.04 & 11.04 & 8.21 \\
\hline $\mathrm{Fa}$ & 3.13 & 4.74 & 3.07 & 4.75 & 7.12 & 8.73 & 9.03 & 7.19 & 5.22 & 3.14 & 3.41 & 10.2 & 3.22 & 6.22 & 4.42 \\
\hline Fo & 11.16 & 8.71 & 8.17 & 6.35 & 5.28 & 3.38 & 2.23 & 4.06 & 4.08 & 12.1 & 10.66 & 11.5 & 11.36 & 10.17 & 10.15 \\
\hline Fs & 6.65 & 5.04 & 3.39 & 3.96 & 3.99 & 2.59 & 1.85 & 2.76 & 2.41 & 7.42 & 6.21 & 6.09 & 7.45 & 6.18 & 6.17 \\
\hline Mt & 4.57 & 4.63 & 6.39 & 4.68 & 4.25 & 4.33 & 4.26 & 4.93 & 3.05 & 4.32 & 4.6 & 4.12 & 4.11 & 4.32 & 4.68 \\
\hline Il & 3.14 & 3.2 & 5.51 & 3.27 & 2.67 & 2.81 & 2.73 & 3.58 & 3.77 & 2.65 & 3.11 & 3.08 & 2.66 & 3.11 & 3.12 \\
\hline Ap & 0.9 & 1.22 & 0.67 & 0.55 & 1.26 & 0.47 & 0.55 & 0.33 & 0.71 & 0.75 & 1.05 & 0.81 & 0.75 & 0.72 & 0.52 \\
\hline
\end{tabular}

Or: orthoclase, Ab: albite, An: anorthite, Ne: nepheline, Wo: wollastinite, En: ensitite, Fa: fayllite, Fo: forsterite, Fs: feroslite, Mt: magnetite, Il: ilmenite, Ap: apatite. 
study can be plotted into the alkaline to the sub-alkaline field (Figure 5(a)). The AFM variation diagram of Figure 5(b) indicates that the compositions of the basaltic rock sample study fall into the tholeiitic to Calc-Alkaline field [26]. According to [27], $\mathrm{Zr} / \mathrm{TiO}_{2}$ verses $\mathrm{Nb} / \mathrm{Y}$ diagram are used for classification, with the $\mathrm{AB}$ rock samples plotted within alkaline basalt (Figure 5(c)).

The data for $\mathrm{Al}_{2} \mathrm{O}_{3}, \mathrm{TiO}_{2}, \mathrm{P}_{2} \mathrm{O}_{5}, \mathrm{FeO}+\mathrm{Fe}_{2} \mathrm{O}_{3}$, and $\mathrm{CaO}$ range between 13.4 and $16.4 \mathrm{wt} \%, 0.2$ to $0.6 \mathrm{wt} \%, 11.1$ to $13.0 \mathrm{wt} \%$, and 7.1 to $12.5 \mathrm{wt} \%$, respectively. A correlation with the determined $\mathrm{SiO}_{2}$ content is only discernable for $\mathrm{Al}_{2} \mathrm{O}_{3}$, shows an increase of $\mathrm{Al}_{2} \mathrm{O}_{3}$ with increasing $\mathrm{SiO}_{2}$ (Figure 6(a)). The binary plot of $\mathrm{SiO}_{2}$ versus $\mathrm{TiO}_{2}, \mathrm{P}_{2} \mathrm{O}_{5}, \mathrm{FeO}+\mathrm{Fe}_{2} \mathrm{O}_{3}$ and $\mathrm{CaO}$ exhibits the inverse relationships between both oxides and $\mathrm{SiO}_{2}$ (Figures 6(b)-(e)). The result is documented within Bowens Series for segregation of the minerals crystallization with basic to acidic type.

The $\mathrm{MgO}$ content of the $\mathrm{AB}$ ranged from $6.08 \mathrm{wt} \%$ to $9.72 \mathrm{wt} \%$ with an average of $7.89 \mathrm{wt} \%$. The $\mathrm{Mg}$ number $(\mathrm{Mg} \neq)$ is defined as the molecular proportion of $\mathrm{Mg}$-values $=\left(\mathrm{Mg} / \mathrm{Mg}+\mathrm{Fe}^{2+}\right)$ [28]. $\mathrm{Mg} \#$ petrogenetic indicator is for magma fractionation and its primitive volcanic rocks [29]. The $\mathrm{AB}$ exhibited a high $\mathrm{Mg} \neq$, ranging between 0.34 and 0.49 , with an average of 0.44 . The $\mathrm{Mg \#}$ of the AVB indicates evolved to moderately basalt. $\mathrm{Mg} \#$ increases with decreasing $\mathrm{SiO}_{2}$ (Figure 6(f)). This general trend suggests that fractional crystallization probably decreasing $\mathrm{Mg}$-number as a function of increasing $\mathrm{SiO}_{2}$ [7].

The determined major and minor element concentrations were also used to
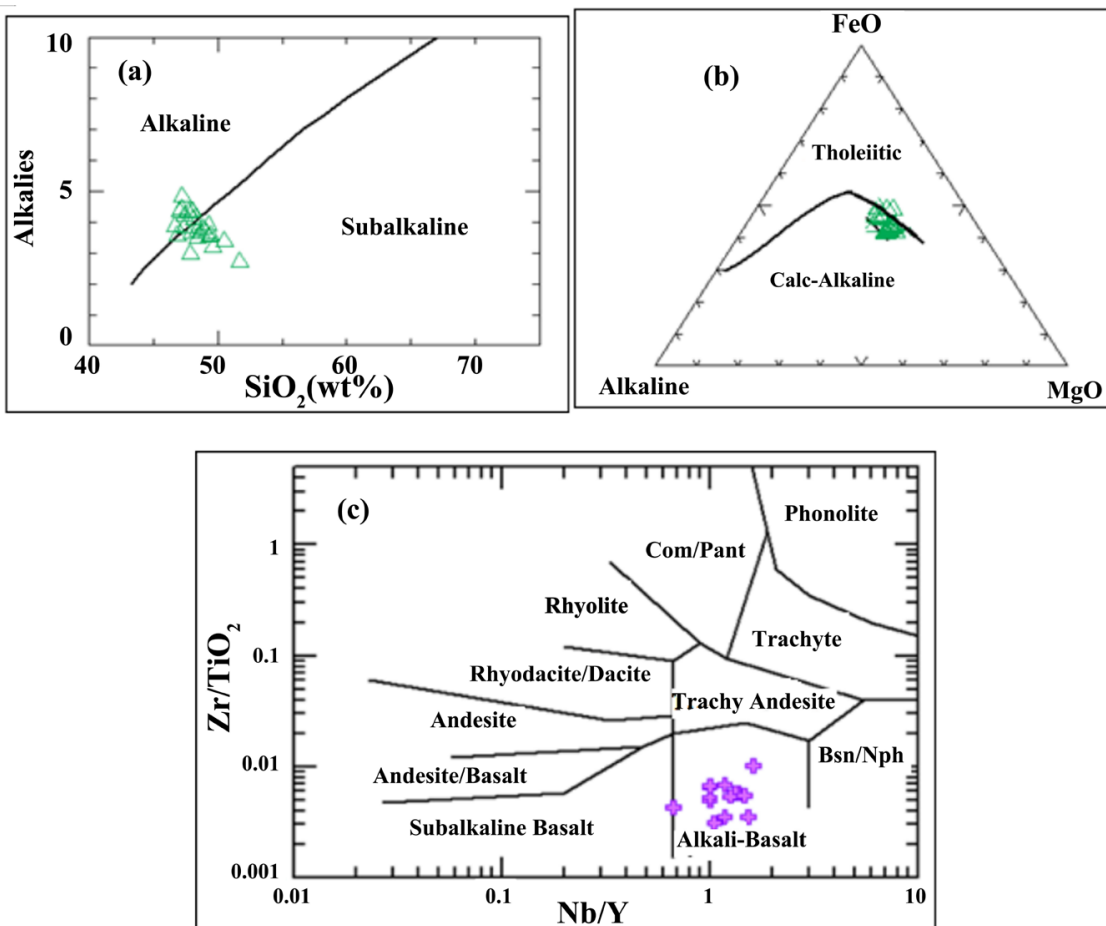

Figure 5. Discrimination plot alkalies- $\mathrm{SiO}_{2}$ after [26]; (b) Alkalis-FeO-MgO (AFM) diagram after [26], all the samples study plotted within Sub-alkaline and Calc-Alkaline field; (c) $\mathrm{Zr} / \mathrm{TiO}_{2}$ vs. $\mathrm{Nb} / \mathrm{Y}$ diagram after [27]. 

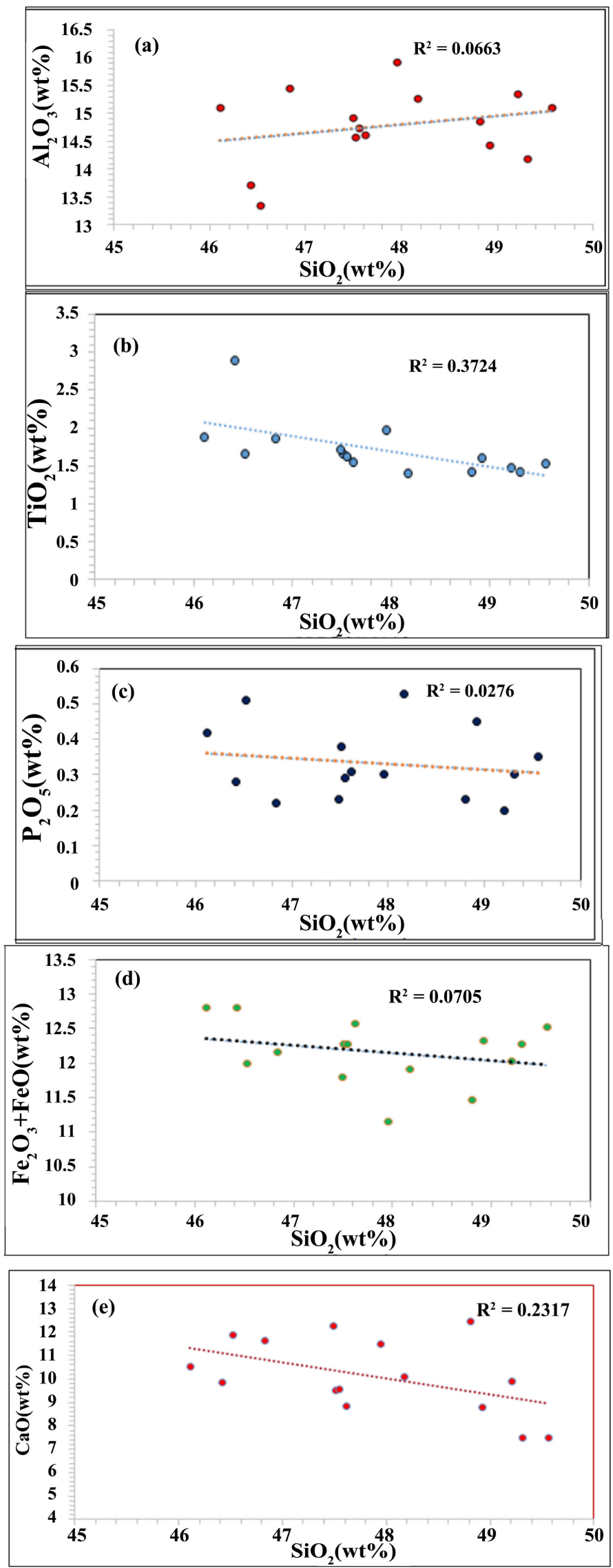


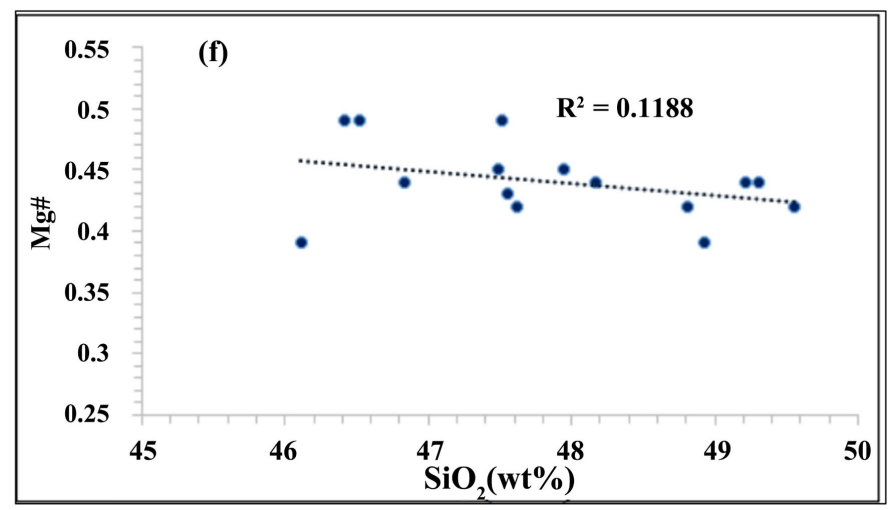

Figure 6. $\mathrm{SiO}_{2}$ versus $\mathrm{Al}_{2} \mathrm{O}_{3}, \mathrm{TiO}_{2}, \mathrm{P}_{2} \mathrm{O}_{5}, \mathrm{FeO}+\mathrm{Fe}_{2} \mathrm{O}_{3}, \mathrm{CaO}$ and $\mathrm{Mg} \#$ for the Atarous $\mathrm{Ba}$ saltic Rock samples study.

calculate the CIPW norm (Table 1). Normative anorthite (An) and albite (Ab) in which $\mathrm{An}$ is higher than $\mathrm{Ab}$ indicated the plagioclase calc alkali nature of these rocks. Apatite and nepheline are present in low percentage. The Ab-An-Or diagram of Figure 7(a), shows the majority of samples reflect the sodic affinity of the rocks. According to [30], diagram $\mathrm{Na}_{2} \mathrm{O}$ verses $\mathrm{K}_{2} \mathrm{O}$, all the samples were plotted within sodic series (Figure $7(\mathrm{~b})$ ). Normative apatite and nepheline contents are below $1.3 \%$ and $4.7 \%$, respectively. The latter content is, however, often zero. As the $\mathrm{FeO}+\mathrm{Fe}_{2} \mathrm{O}_{3}$ show scatter in a plot versus $\mathrm{SiO}_{2}$ Figure 6(d), this could reflect a decreasing degree of partial melting of a relatively homogenous source.

The chemical analysis of Atarous Basalt samples was found to have a high content of $\mathrm{Cr}$ and $\mathrm{Ni}$ (Table 1). The $\mathrm{Cr}$ content varied between 106 and 162 ppm, with an average value of $131.73 \mathrm{ppm}$. The Ni content ranges between 73 and $168 \mathrm{ppm}$ with an average of $132.71 \mathrm{ppm}$, suggesting $\mathrm{AB}$ fractionation by the presence of olivine and clinopyroxene [31]. The high concentration of $\mathrm{Cr}$ and $\mathrm{Ni}$ indicated that the parental magma had been derived through partial melting of peridotite mantle source [2] and [7]. The binary diagram (Figure 8) shows the $\mathrm{Mg} \#$ versus $\mathrm{Cr}$ and $\mathrm{Ni}$. The general trend is a decrease of $\mathrm{Cr}$ and $\mathrm{Ni}$ with increasing Mg\#; this result is documented with Zarqa-Ma'in basalt, Ar-Rabba Basalt and Mudawwara-Quwayra Basaltic Dike [32] [33] [34]. These results were documented with [7], for the crustal mixing and assimilation of magma of the country rocks and dilution of $\mathrm{Cr}$ and $\mathrm{Ni}$.

The contents of $\mathrm{Sr}, \mathrm{Zr}, \mathrm{Pb}$ and $\mathrm{Ba}$ range between 325 to 5500 with an average of $1403 \mathrm{ppm}$; 60 to $145 \mathrm{ppm}$, average $93.41 ; 15$ to $100 \mathrm{ppm}$, average 64.12; and 35 to $265 \mathrm{ppm}$ with an average of 111.23 , respectively.

The Rare Earth Elements (REE) concentration includes Rb, Nb, Y, Ce and Sc and have low scattering around 7 to $16 \mathrm{ppm}$ with an average of $10.88 ; 10$ to 40 ppm with an average of $21.12 ; 11$ to 26 with an average of $17.41 ; 22$ to $70 \mathrm{ppm}$ an average of 45; and 17 to $33 \mathrm{ppm}$ with an average of 24.75 , respectively (Table 1 ). The average ratio between $\mathrm{Zr} / \mathrm{Nb}=4.93 \mathrm{Zr} / \mathrm{Y}=5.58$ and $\mathrm{Y} / \mathrm{Nb}=0.91$. This ratio was documented by [34] [35], reported for the intercontinental alkali basalt. On 

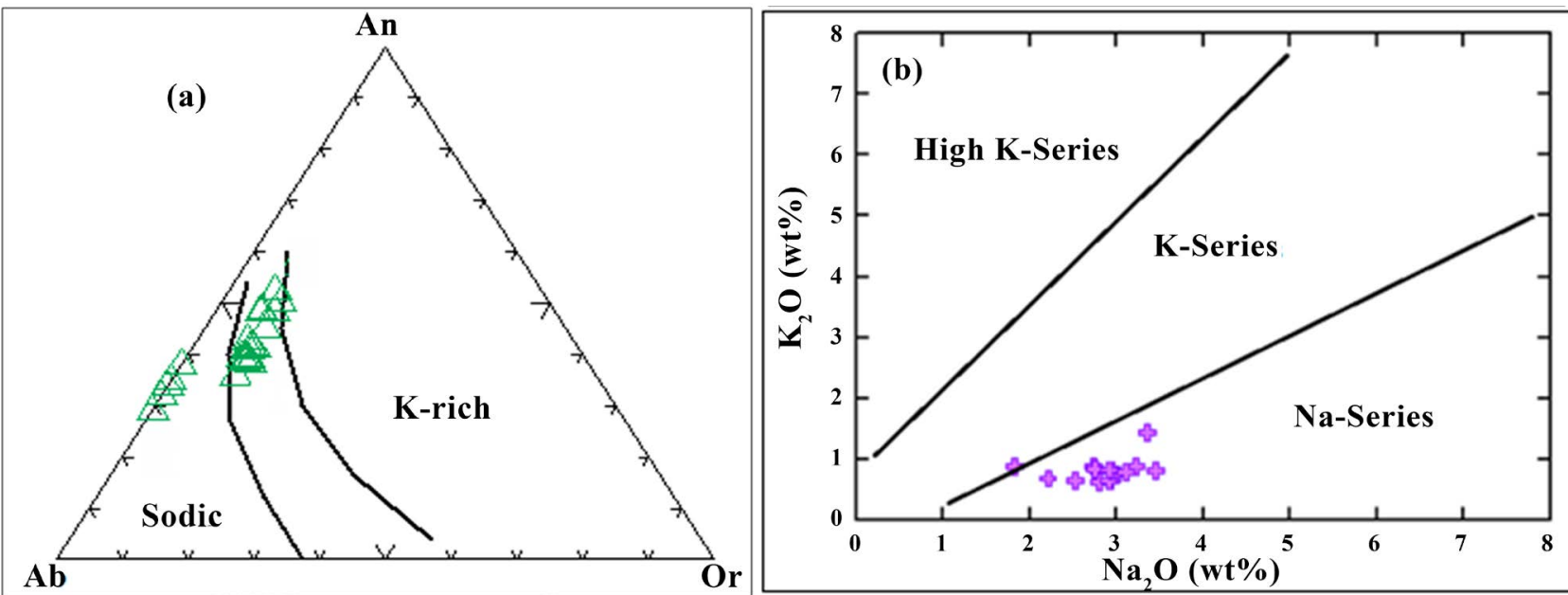

Figure 7. Triangular discrimination plot for (a) Ab-Or-An after [26]; (b) $\mathrm{K}_{2} \mathrm{O}$ vs. $\mathrm{Na}_{2} \mathrm{O}$ diagram, after [30].
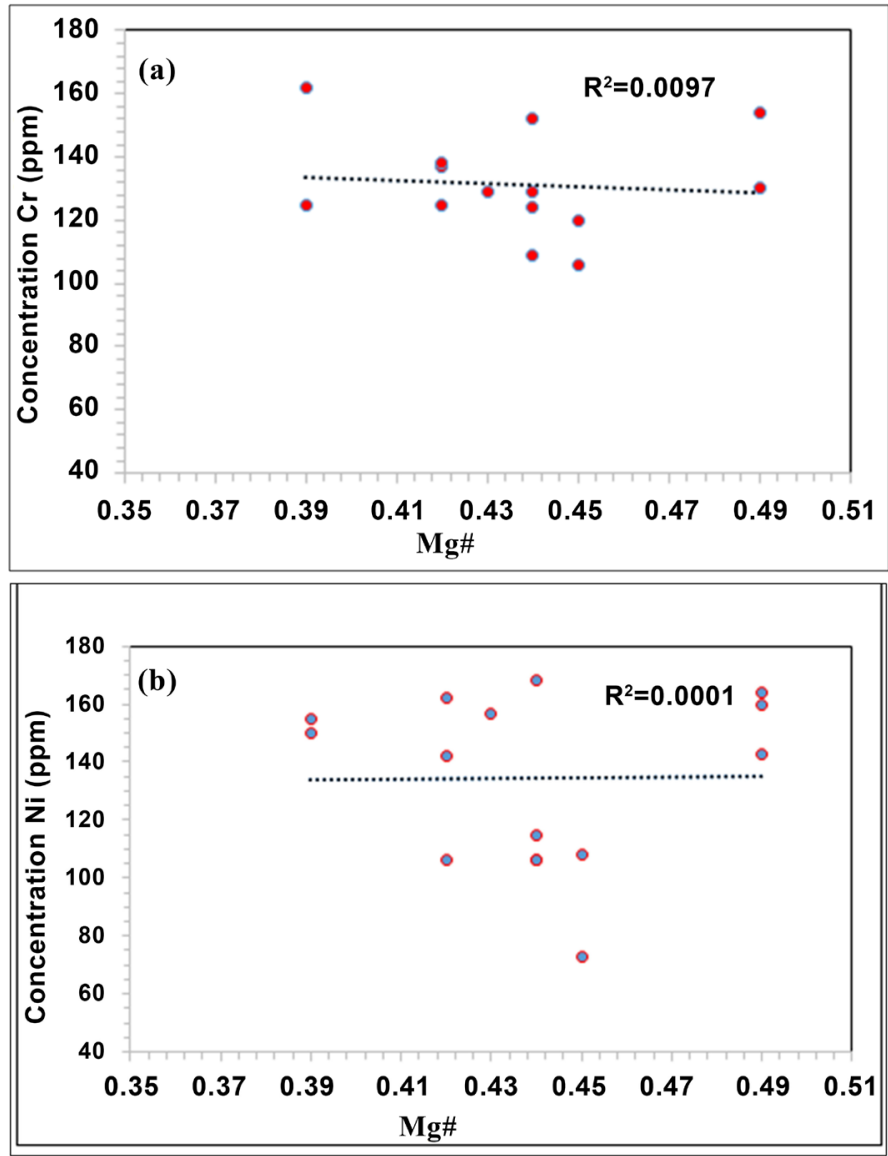

Figure 8. Binary diagram (a) Mg\# verses $\mathrm{Cr}$ and (b) Mg\# verses Ni.

the other hand, Ti-Zr-Sr diagram shows all the study samples (AB) were plotted within the plate field basalt (Figure 9(a)) [36]. The Nb-Zr-Y diagram shows the AB samples plotted within the alkali basalt field (Figure 9(b)) [37]. The Ti-Zr-Y diagram shows all the study samples plotted within Calk alkaline basalt field (Figure 9(c)) [38]. 



Figure 9. (a) Ti-Zr-Y diagram [38]; (b) Zr-Nb-Y diagram [37]; (c) Ti-Zr-Sr diagram for $\mathrm{AB}[38]$.

The geochemical information for major and trace elements are used to explain the natural source of $A B$, and it can be used to explain the mantle sources of partial melting. This indicates by using trace element ratios, such as $\mathrm{Zr} / \mathrm{Nb}$ (average 
4.93) and $\mathrm{K} / \mathrm{Ba}$ (average 0.011) ratios [39]. The high content of $\mathrm{Zr} / \mathrm{Y}$ (average 5.58) and $\mathrm{TiO}_{2} / \mathrm{Y}$ (average 1.92) ratios and low content of $\mathrm{Y}$ (average $17.41 \mathrm{ppm}$ ) indicate that to the garnet-bearing source rocks [40]. The spider diagram for Rock Primordial mantle for the studied volcanic rock samples (AB) (Figure 10) presented enrichment of the incompatible LILE such as $\mathrm{Ba}$ and $\mathrm{K}$, depletion of $\mathrm{Nb}$ relatively to $\mathrm{K}$, and enrichment $\mathrm{Nb}$ and $\mathrm{Ce}$ and depletion with $\mathrm{Y}$. The mafic volcanic $\mathrm{AB}$ exhibited positive $\mathrm{Nb}, \mathrm{Ce}$ and $\mathrm{Ti}$ anomalies. The negative anomalies of $\mathrm{Ba}, \mathrm{Sr}$, and $\mathrm{P}$ may be attributed to the fractionation of feldspar for $\mathrm{Ba}$ and $\mathrm{Sr}$ depletion apatite for $\mathrm{P}$ depletion, and ( $\mathrm{Fe}-\mathrm{Ti}$ ) oxides for $\mathrm{Ti}$ depletion [41]. The Rock Primordial mantle value of the rock (Figure 10) showed a positive $\mathrm{Nb}$ peak, which conforms to the tertiary to recent continental alkali basalt provinces [42] [43] [44] and indicates that the $\mathrm{AB}$ is the product of lithosphere from upwelling asthenosphere mantle [23] [29].

\section{Discussion}

The studied basalts $(\mathrm{AB})$ are alkaline to sub-alkaline with respect to silica content and often $\mathrm{SiO}_{2}$-undersaturated. Similar rock compositions were reported by [18] [19] [20] [23] [46] [47] from NE and central Jordan. The Arabia lithospheric mantle beneath Jordan is chemically and isotopically heterogeneous. According to [48], it is possible that the volcanic rock was sourced from lower lithosphere depth. Cenozoic interpalate volcanic fields throughout Arabia may be the product the melting of upper mantle wedge material fertilized during Pan-African subduction and incorporated into the Arabian Lithospheric mantle [48]. The primary alkali basalt can be formed by low degree of melting at a pressure as low as $13 \mathrm{kbar}$ and can fractionate to tholeiitic liquids between 4 and $12 \mathrm{kbar}$ [49]

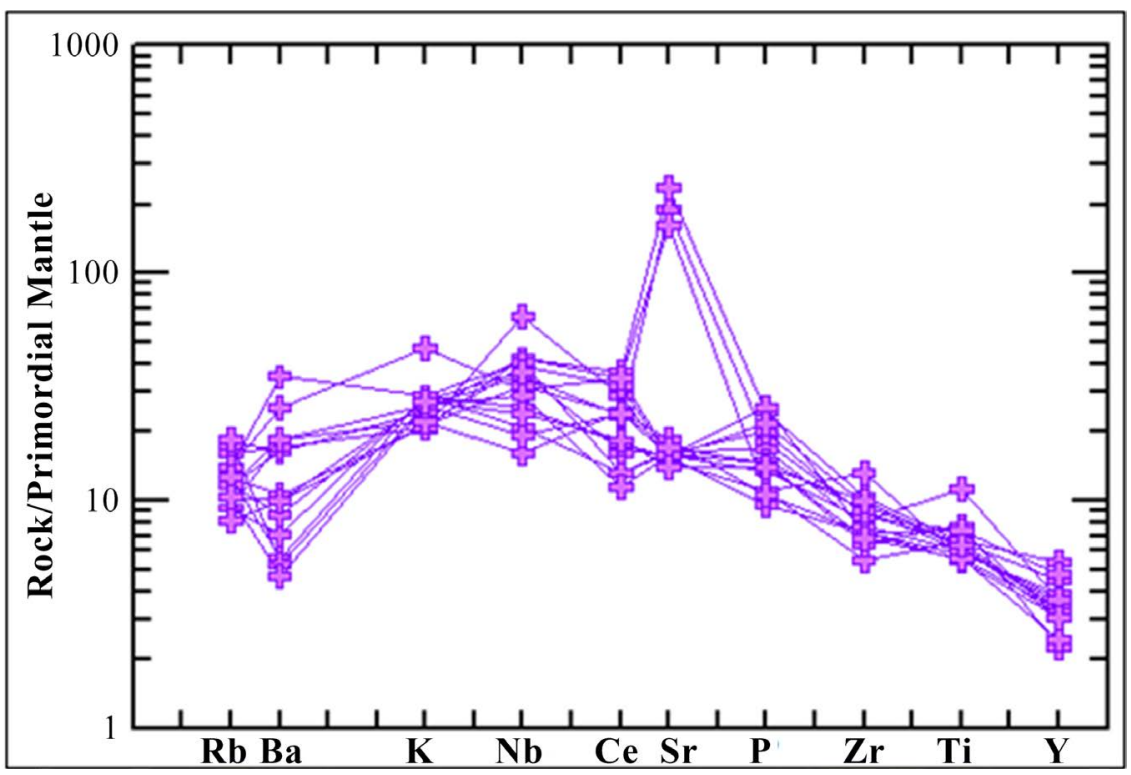

Figure 10. Spider diagram of incompatibility elements from the Atarous Basalt study; Rock/Primordial mantle for trace element abundance patterns of the basaltic rocks after [45]. 
[50]. The alkali basalt melts can be derived in the low-velocity zonation approximate depths of $85-95 \mathrm{~km}, 30 \mathrm{kbar}$ by about $5 \%$ partial melting and by about $10 \%$ in the Lithosphere, at $60-90 \mathrm{~km}$ and $19-27 \mathrm{kbar}$ [51]. Basalt may be both direct products of mantle partial melting and the differentiates of more primitive picritic partial melts [7]. However, the $\mathrm{Mg}$-values $\left(\mathrm{Mg} / \mathrm{Mg}+\mathrm{Fe}^{2+}\right)$ ranging from 0.39 to 0.49 (Table 1) could point to little fractional crystallization and removal of olivine and pyroxene. Nickel and Cr vary between $73-168 \mathrm{ppm}$ and $106-162 \mathrm{ppm}$, respectively. These concentrations also suggest some degree of olivine fractionation, which tends to increase the incompatible trace element concentration in the studied basalts. The basalt of Al-Qiranha volcano in central Jordan is indicative of a primitive upper mantle that has suffered partial melting at a temperature ranging between $1050^{\circ} \mathrm{C}$ and $1210^{\circ} \mathrm{C}$ and pressure $15-20 \mathrm{kbar}$ [18]. Based on the pre-mentioned information [52] that the recent basalt of Ethiopian rift was produced as a small degree partial melting peridotite of 15 $25 \mathrm{kbarm}$, [53] also suggested that the basalts from central France, which are similar in their mineralogy to those of central Jordan volcano, were produced by partial melting of spinel lherzolite at $16-20$ kbar pressure. The geochemistry of alkaline basalt indicates a source for intraplate volcanism [48]. The Ti richness could be attributed to low degrees of melting of peridotite source [54]. The basalt flow from Ar-Rabba, the main Ash-Shamaliyya area of central and northwest Jordan, is produced within the intraplate to continental calc-alkaline to alkali basalt [32] [33].

Seismic and gravity data indicate that the crust below this field is about $35 \mathrm{~km}$ [55]. The source of Arabian intraplate basalt, suggesting that the numerous Cenozoic intraplate volcanic fields throughout Arabia may be the product of melting upper mantle wedge material fertilized during Pan-African subduction and incorporated into the Arabian, Lithospheric mantle [48] and [56].

The primary alkali basalts can be formed by low degree of melting, as they are similar in their mineralogy to those of central Jordan volcano produced by partial melting of spinel lherzolite at $16-20 \mathrm{kbar}$ pressure. The investigated volcano resulted from magma rich in volatile constituents lost explosively from a central vent like an eruption, and the magma reflects the presence of spinel lherzolite nodules present in the same area that did not equilibrate with the melt, indicating that the transport from the upper mantle to the surface was rapid. Thus, the consideration of trace elements and mantle xenoliths support the concept that lava from central Jordan (include Atarous Basalt) has been derived from the upper mantle with a low degree of melting $<15 \%$.

\section{Conclusions}

The Atarous Basalt (AB) was introduced within Miocene to Pleistocene volcanism at central Jordan. It is produced within intraplate to continental alkali basalt to calc-alkaline. The samples study covered Atarous Volcanic Basalt flow about 8 $\mathrm{km}^{2}$. The following is the conclusion of the present study: 
1) The mineral composition of $\mathrm{AB}$ is as follows: plagioclase, pyroxene (augite), olivine, secondary minerals such as iddingsite and chlorite by alteration of olivine and pyroxene (chlorination). Accessory minerals include apatite and opaque minerals, magnetite, ilmenite and spinel. The texture observed porphyritic and trachytic texture.

2) The chemical classification of $A B$ had Alkaline to calc-alkaline basalt and includes sodic series.

3) The tectonic setting for the discrimination diagram showed that the $A B$ samples in the study were plotted within plate basalt, alkali basalt and Calc-alkaline basaltic field.

4) The spider diagram for Rock Primordial mantle for the studied volcanic rock samples $(\mathrm{AB})$ shows enrichment of the incompatible LILE such as $\mathrm{Ba}$ and $\mathrm{K}$, and depletion of $\mathrm{Nb}$ relatively to $\mathrm{K}$, and enrichment $\mathrm{Nb}$ and $\mathrm{Ce}$ and depletion of $Y$.

5) The mafic volcanic rocks of $\mathrm{AB}$ exhibited positive $\mathrm{Nb}$ and $\mathrm{Ce}$ anomalies, and negative anomalies of $\mathrm{Ba}, \mathrm{Sr}, \mathrm{P}$, and $\mathrm{Ti}$ may be attributed to the fractionation of feldspar for $\mathrm{Ba}$ and $\mathrm{Sr}$ depletion apatite for $\mathrm{P}$ depletion.

6) The Spider diagram for Rock Primordial mantle for the rock sample study showed a positive $\mathrm{Nb}$ peak, which conforms to recent continental alkali basalt provinces; these indicates to the $\mathrm{AB}$ produced of lithosphere from upwelling asthenosphere mantle.

\section{Acknowledgements}

The author is thankful to the laboratory of the University of Stuttgart, Germany, for help with analysis of major and trace elements using X-Ray Fluorescence Spectrometry (XRF) at the Department of Geology. The author is also grateful to Jordan University, geology department for help with the preparation of thin sections.

\section{Conflicts of Interest}

The authors declare no conflicts of interest regarding the publication of this paper.

\section{References}

[1] Barberi, F., Capaldi, P., Gasperihi, G., Marinelli, G., Santacroce, R., Treuil, M. and Varet, J. (1979) Recent Basaltic Volcanism of Jordan and Its Implication on the Geodynamic History of the Dead Sea Shear Zone. In: International Symposium Geodynamic Evolution of the Afro-Arabian Rift System, Academia Nazionale Dei Lincei 47, Rome, 667-683.

[2] Shaw, J.E., Baker, J.A., Menzies, M.A., Thirl wall, M.F. and Ibrahim, K.M. (2003) Petrogensis of the Largest Intraplate Volcanic Field on the Arabian Plate (Jordan): A Mixed Lithosphere-Asthenosphere Source Activated by Lithospheric Extension. Journal of Petrology, 44, 1657-1679. https://doi.org/10.1093/petrology/egg052

[3] Ibrahim, K. and Al-Malabeh, A. (2006) Geochemistry and Volcanic Features of 
Harrat El-Fahda, a Young Volcanic Field in Northwest Arabia, Jordan. Journal of Asian Sciences, 127, 127-154. https://doi.org/10.1016/j.jseaes.2005.01.009

[4] Moffat, D. (1988) A Volcano Tectonic Analysis of the Cenozoic Continental Basalts of Northern Jordan: Implications for Hydrocarbon Prospectively in the Block B Area. Unpublished Report, University College of Swansea, Swansea.

[5] Bender, F. (1974) Geology of the Arabian Peninsula, Jordan. US Geological Survey Professional Paper, 36, 560-561. https://doi.org/10.3133/ofr74215

[6] Fediuk, F. and Al-Fugha, H. (1999) Dead Sea Region Fault-Controlled Chemistry of Cenozoic Volcanics. Geolines (Praha), 9, 29-34.

[7] Wilson, M. (1989) Igneous Petrogenesis, a Global Tectonic Approach. 2nd Edition, Unwin Hyman, London, 466 p. https://doi.org/10.1007/978-1-4020-6788-4

[8] Shaw, J. (2003) Geochemistry of Cenozoic Volcanism and Arabian Lithospheric Mantle in Jordan. PhD Thesis, Royal Holloway University of London, London, 268 p.

[9] Duffield, W., Mckee, E., El-Salem, F. and Feimeh, M. (1988) K-Ar Ages Chemical Composition and Geothermal Significance of Cenozoic Basalt near the Jordan Rift. Geothermics, 17, 635-644. https://doi.org/10.1016/0375-6505(88)90048-X

[10] Tarawneh, K., Ilani, S., Rabba, I., Harlavan, Y., Peltz, S., Ibrahim, K., Weinberger, R. and Steinitz, G. (2000) K-Ar Dating of the Harrat Ash Shaam Basalts, Northeast Jordan. Natural Resources Authority and Geological Survey of Israel, Report GSI 2/2000, 45 p.

[11] Ilani, S., Harlavan, Y., Tarawneh, K., Rabba, I., Weinberger, R., Ibrahim, K., Peltz, S. and Steinitz, G. (2001) New K-Ar Ages of Basalts from the Harrat Asham Volcanic Field in Jordan: Implications for the Span and Duration of Upper Mantle Upwelling beneath the Western Arabian Plate. Geology, 29, 171-174. https://doi.org/10.1130/0091-7613(2001)029<0171:NKAAOB >2.0.CO;2

[12] Steinitz, G. and Bartov, Y. (1992) The Miocene-Pleistocene History of the Dead Sea Segment of the Rift in Light of K-Ar Ages of Basalts. Israel Journal of Earth Sciences, 40, 199-208.

[13] Al-Fugha, H. (1996) Basanites with Mantle Xenoliths from Jabal El-Dabusa in West Central Jordan. Mutah Journal, 11, 35-53.

[14] White, R.S. and McKenzie, D. (1989) Magmatism at Rift Zones the Generation of Volcanic Continental Margins and Flood Basalts. Journal of Geophysical Research, 94, 7685-7730. https://doi.org/10.1029/JB094iB06p07685

[15] McGuire, A.V. and Bohannon, R.G. (1989) Timing of Mantle Upwelling: Evidence for a Passive Origin of the Red Sea Rift. Journal of Geophysical Research B, 94, 1677-1682. https://doi.org/10.1029/JB094iB02p01677

[16] Garfunkel, Z. (1989) Tectonic Setting of Phanerozoic Magmatism in Israel. Israel Journal of Earth Sciences, 38, 51-74.

[17] Weinstein, Y., Navon, O., Altherr, R. and Stein, M. (2006) The Role of Lithospheric Mantle Heterogenity in the Generation of Plio-Pleistocene Alkali Basaltic Suites from NW Harrat Ash Shaam. Journal of Petrology, 47, 1017-1050. https://doi.org/10.1093/petrology/egl003

[18] Al-Fugha, H. (1995) Spinel-Lherzolite Xenoliths from Jabal Al-Qiranah Basalt Central Jordan. Mutah Journal, 10, 1-14.

[19] Al-Fugha, H. (2006) Petrology and Geochemistry of Upper Mantle Xenoliths from Tel-Remah Volcano. NE Jordan Mu' tah Journal, 21, 17-30.

[20] Al-Fugha, H. and Al-Amaireh, M. (2007) Petrology and Origin of Ultramafic Xenoliths from Northeastern Jordan Volcanoes. American Journal of Applied Sciences, 
4, 491-495. https://doi.org/10.3844/ajassp.2007.491.495

[21] Yazdi, A., Ashja-Ardalan, A., Emami, M., Dabiri, R. and Foudazi, M. (2017) Chemistry of Minerals and Geo Thermobarometry of Volcanic Rocks in the Region Located in Southeast of Bam Kerman Province. Open Journal of Geology, 7, 1644-1653. https://doi.org/10.4236/ojg.2017.711110

[22] Morimoto, N. (1988) Nomenclature of Pyroxenes. Mineralogical Magazine, 52, 535-550. https://doi.org/10.1180/minmag.1988.052.367.15

[23] El-Hasan, T. and Al-Malabeh, A. (2008) Geochemistry, Mineralogy and Petrogenesis of El-Lajjoun Pleistocene Alkali Basalt of Central Jordan. Jordan Journal of Earth and Environmental Sciences, 1, 53-62.

[24] Le Maitre, R.W., Bateman, P., Dudek, A., Keller, J., Lameyre Le Bas, M.J., Sabine, P.A., Schmid, R., Sorensen, H., Streckeisen, A., Woolley, A.R. and Zanettin, B. (1989) A Classification of Igneous Rocks and Glossary of Terms. Blackwell, Oxford.

[25] Cox, K., Bell, J. and Pankhurst, R. (1979) The Interpretation of Igneous Rocks. Springer, London. https://doi.org/10.1007/978-94-017-3373-1

[26] Irvin, T.N. and Baragar, W.R. (1971) A Guide to the Chemical Classification of the Volcanic Rocks. Canadian Journal of Earth Sciences, 8, 523-548. https://doi.org/10.1139/e71-055

[27] Winchester, J.A. and Floyd, P.A. (1977) Geochemical Discrimination of Different Magma Series and Their Differentiation Products Using Immobile Elements. Chemical Geology, 20, 325-343. https://doi.org/10.1016/0009-2541(77)90057-2

[28] Downes, H., Seghed, I., Szakacs, A., Dobasi, G., James, D., Vaselli, O., Rigby, I., Ingram, G., Rex, D. and Peckskay, Z. (1995) Petrology and Geochemistry of Late Tertiary-Quaternary Mafic Alkali Volcanism in Romania. Lithos, 35, 65-81. https://doi.org/10.1016/0024-4937(95)91152-Y

[29] Ma, G.S.-K., Malpas, J., Xenophontos, C. and Chan, G.H.-N. (2011) Petrogenesis of Latest Miocene-Quaternary Continental Intraplate Volcanism along the Northern Dead Sea Fault System (Al-Ghab-Homs Volcanic Field), Western Syria: Evidence for Lithosphere-Asthenosphere Interaction. Journal of Petrology, 52, 401-430. https://doi.org/10.1093/petrology/egq085

[30] Middlemost, E.A.K. (1975) The Basalt Clan. Earth Science Reviews, 11, 337-364. https://doi.org/10.1016/0012-8252(75)90039-2

[31] Winter, J.D. (2001) An Introduction to Igneous and Metamorphic Petrology. Prentice Hall Inc., Upper Saddle River, 697.

[32] Bany Yaseen, I. (2014) Contribution to the Petrography, Geochemistry, and Petrogensis of Zarqa-Ma'in Pleistocene Alkali Olivine Basalt Flow of Central Jordan. International Journal of Geosciences, 5, 657-672. https://doi.org/10.4236/ijg.2014.56059

[33] Alnawafleh, H., Tarawneh, K., Ibrahim, K., Zghoul, K., Titi, A., Rawashdeh, R., Moumani, K. and Masri, A. (2015) Characterization and Origin of the Miocene Mudawwara-Quwayra Basaltic Dike, Southern Jordan. International Journal of Geosciences, 6, 869-881. https://doi.org/10.4236/ijg.2015.68071

[34] Bany Yaseen, I. (2016) Petrography, Geochemistry and Petrogensis of Basalte Flow frome Ar-Rabba Area, Central Jordan. International Journal of Géosciences, 7, 378-396. https://doi.org/10.4236/ijg.2016.73030

[35] Pearce, J., Harris, N. and Tindle, A. (1984) Trace Element Discrimination Diagram for the Tectonic Interpretation of Granitic Rocks. Journal of Petrology, 25, 956-983. https://doi.org/10.1093/petrology/25.4.956 
[36] Pearce, J.A. and Cann, J.R. (1973) Tectonic Setting of Basic Volcanic Rocks Determined Using Trace Element Analyses. Earth and Planetary Science Letters, 19, 290-300. https://doi.org/10.1016/0012-821X(73)90129-5

[37] Meschede, M. (1986) A Method of Discriminating between Different Types of Mid-Ocean Ridge Basalts and Continental Tholeiitic with the Nb-Zr-Y Diagram. Chemical Geology, 56, 207-218. https://doi.org/10.1016/0009-2541(86)90004-5

[38] Pearce T.H., Gorman, B.E. and Birkett, T.C. (1977) The Relationship between Major Element Chemistry and Tectonic Environment of Basic and Intermediate Volcanic Rocks. Earth and Planetary Science Letters, 36, 121-132. https://doi.org/10.1016/0012-821X(77)90193-5

[39] Peltz, S. and Bratosia, W. (1986) New Data on the Geochemistry of the Quaternary Basalts in Pensani Mountains. Geophics, 71, 389-403.

[40] Jenner, G., Gawood, P., Rautenschlein, M. and White, W. (1987) Composition of Back-Arc Basin Volcanic Valufa Ridge Lau Basin: Evidence for a Slab-Derived Component in Their Mantle Source. Journal of Volcanology and Geothermal Research, 32, 209-222. https://doi.org/10.1016/0377-0273(87)90045-X

[41] Moghazi, A.M. (2003) Geochemistry and Petrogenesis of a High-K Calc-Alkaline Dokhan Volcanic Suite, South Safaga Area, Egypt: The Role of Late Neoproterozoic Crustal Extension. Precambrian Research, 125, 161-178. https://doi.org/10.1016/S0301-9268(03)00110-4

[42] Sun, S.S. and Mac Donough, W.F. (1989) Chemical and Isotopic Systematic of Oceanic Basalts Implications for Mantle Composition and Processes in Magmatism in the Ocean Basins. Geological Society, London, Special Publication, 42, 313-345. https://doi.org/10.1144/GSL.SP.1989.042.01.19

[43] El-Akhal, H. (2004) Contribution to the Petrography, Geochemistry and Tectonic Setting of the Basalt Flows of the Umm-Qais Plateau, North Jordan. Geological Bulletin of Turkey, 47, 1-10.

[44] Al-Malabeh, A. (2009) Cryptic Mantle Metasomatism: Evidences from Spinel Lherzolite Xenoliths/Al-Harida Volcano in Harrat Al-Shaam, Jordan. American Journal of Applied Sciences, 6, 2085-2092. https://doi.org/10.3844/ajassp.2009.2085.2092

[45] Thompson, R.N. (1987) Phase-Equilibria Constraints on the Genesis and Magmatic Evolution of Oceanic Basalts. Earth-Science Reviews, 24, 161-210. https://doi.org/10.1016/0012-8252(87)90023-7

[46] Nasir, S. (1994) Geochemistry and Petrogenesis of Cenozoic Volcanic Rocks from the Northwestern Part of the Arabian Continental Alkali Basalt Province, Jordan. Africa Geoscience Review, 1, 455-467.

[47] Nasir, S. (1995) Mafic Lower Crustal Xenoliths from the Northwestern Part of the Arabian Plate. European Journal of Mineralogy, 7, 217-230. https://doi.org/10.1127/ejm/7/1/0217

[48] Shaw, J.E., Baker, J.A., Kent, A.R., Ibrahim, K.M. and Menzies, M.A. (2007) The Geochemistry of the Arabian. Lithospheric Mantle a Source for Intraplate Volcanism. Journal of Petrology, 48, 1495-1512. https://doi.org/10.1093/petrology/egm027

[49] Mysen, B.O. and Kushiro, R. (1977) Compositional Variation of Coexisting Phases with Degrees of Melting of Peridotite in the Upper Mantle. American Mineralogist, 62, 843-865.

[50] Shervais, J.W. and Vetter, S.K. (2009) High-K Alkali Basalts of the Western Snake River Plain: Abrupt Transition from Tholeitic to Mildly Alkaline Plume-Derived Basalts. Journal of Volcanolgy and Geothermal Research, 188, 141-152. 
https://doi.org/10.1016/j.jvolgeores.2009.01.023

[51] Green, D.H. (1970) A Review of Experimental Evidence on the Origin of Basaltic and Nephelinitic Magmas. Physics of the Earth and Planetary Interiors, 3, 221. https://doi.org/10.1016/0031-9201(70)90060-9

[52] Rooney, T.O., Furma, T., Yirgu, G. and Ayalew, D. (2005) Structure of Ethiopian Lithophere: Xenolith Evidence in the Main Ethiopian Rift. Geochimica et Cosmochimica Acta, 69, 3889-3910. https://doi.org/10.1016/j.gca.2005.03.043

[53] Thompson, R.N., Gibson, L., Mariner, G.J., Nattey, D.P. and Morrison M.A.J. (1980) Primary Basalt, Magma Genesis. Central France Petrl., 21, 265-293.

[54] Shehata, A. and Theodoros, N. (2011) Alkali Basalts from Burgenland, Austria Petrological Constraints on the Origin of the Westernmost Magmatism in the Carpathian-Pannonian Region. Lithos, 121, 176-188. https://doi.org/10.1016/j.lithos.2010.11.001

[55] Sawaf, T., Al-Saad, D., Gebran, A., Barazangi, M., Best, A. and Chiamov, T. (1993) Stratigraphy and Structure of Eastern Syria across the Euphrates Depression. Tectonophysics, 230, 267-281. https://doi.org/10.1016/0040-1951(93)90235-C

[56] Al-Safarjalani, A., Nasir, S., Fockenberg, T. and Massonne, H.-J. (2009) Chemical Composition of an Intermediate Part of the Lower Crust beneath South Western Syria. Chemie der Erde-Geochemistry, 69, 359-375.

https://doi.org/10.1016/j.chemer.2009.05.005 